Human and Animal Health

Vol.60: e17160127, January-December 2017 http://dx.doi.org/10.1590/1678-4324-2017160127 ISSN 1678-4324 Online Edition

\title{
Enterococcus spp. Resistant to Multiple Antimicrobial Drugs and Determination of Fecal Contamination Levels in Mangrove Oysters (Crassostrea rhizophorae)
}

\author{
Cynthia Annes Rubião ${ }^{1 *}$, Robson Maia Franco ${ }^{1}$, Eliana de Fátima Marques de Mesquita ${ }^{1}$, \\ Marco Antonio Lemos Miguel ${ }^{2}$, Claudius Couto Cabral ${ }^{1}$, Ana Beatriz Monteiro Fonseca ${ }^{3}$. \\ ${ }^{1}$ Universidade Federal Fluminense Faculdade de Veterinária - Tecnologia de Alimentos, Niterói, Brazil; \\ ${ }^{2}$ Universidade Federal do Rio de Janeiro - Instituto de Microbiologia Paulo de Góes; ${ }^{3}$ Universidade Federal \\ Fluminense -Instituto de Matemática e Estatística.
}

\begin{abstract}
The aim of this study was to determine and compare the Most Probable Number (MPN) of Total Coliforms (TC), Escherichia coli and Enterococcus spp. and to characterize the antimicrobial resistance profiles of Enterococcus spp. isolated from oysters collected in the Barra de Guaratiba Mangrove, Rio de Janeiro, Brazil. The enumeration of $\mathrm{E}$. coli has been used to indicate fecal contamination and hygienic-sanitary conditions of bivalve molluscs. Enterococci are capable to transfer several antimicrobial resistance genes to pathogenic bacteria, including those from Gram-negative group. The oysters were bought from local fishermen and a total of 123 individuals were analyzed. The TC, E. coli and Enterococcus spp. MPN mean were 26,300/100 g, 3,260/100 g and 2,820/100 g, respectively. The only correlation found was between TC and E. coli. Two strains of Enterococcus spp. were resistant to three different antimicrobial categories, including a high level resistance to streptomycin. One strain presented intermediate resistance to vancomycin. The E. coli levels exceeded the limits established by international legislation. This microbiological contamination in oysters reflects the water pollution and indicates a probable contamination of other seafood species from this mangrove, which can represent a risk for consumers and a threat to the environment and public health.
\end{abstract}

Key words: water pollution, Escherichia coli, Enterococcus spp., antimicrobial resistance, bivalve molluscs.

\footnotetext{
*Author for correspondence: cynthiaar01@gmail.com
} 


\section{INTRODUCTION}

Oysters are traditionally eaten raw, what may represent a serious public health concern since these molluscs are filter feeders and may accumulate a number of different pathogenic microorganisms in their soft tissue and palial fluid. As such, food safety experts and public health agencies have consistently warned about the serious potential risk when these molluscs are consumed uncooked. On the other hand, oysters can be used as bioindicators of the ambient water quality and other shellfish safety for human consumption.

Mangrove habitats are considered important natural nurseries that can support up to $30 \%$ of the coastal fishery, besides providing food, employment and income for many coastal communities ${ }^{1}$. Nevertheless, these habitats have been threatened by an intense pollution, including sewage that may contain Escherichia coli at dangerous levels and Enterococcus spp. resistant to multiple antimicrobial drugs ${ }^{1,2,3}$.

The infections caused by multidrug resistant bacteria are a growing threat for global public health because they represent a significant risk for the progress of modern medicine ${ }^{4}$.The pharmaceutical industry has not been able to develop new drugs with the same speed bacteria can build up resistance to the existing and even the recently developed drugs. Frequently, there are fewer and very toxic, or even none, effective antimicrobial agents available to treat these infections. At the present time, the return to pre-antibiotic era, when common infections could kill, is being considered a concrete scenario for human society ${ }^{4,5}$. In addition to the possibility of a foodborne disease involving a multidrug resistant bacteria, there is another concern related to animal origin products: gene transfer from bacteria as Enterococcus spp. to other clinically relevant Gram-negative and Gram-positive bacteria as E.coli and Methicillin resistant Staphylococcus aureus 4, 6, 7, 8, 9, 10, 11. Since the genome of Enterococcus spp. may easily change and adapt, the continuous exposure of these bacteria to different antimicrobial categories may induce the emergence of Enterococcus spp. strains that are virtually resistant to all clinically relevant antimicrobial agents ${ }^{12}$. Initially silent, these bacteria can colonize the human gastrointestinal tract and then cause infections that will not be promptly recognized as foodborne related ${ }^{4,13}$. The antimicrobial resistance profiles of Enterococcus spp. bacteria isolated from food samples have been studied by many authors. But there are few reports about the antimicrobial resistance profiles in marine animals (and, more specifically, oysters) compared with terrestrial animals.

Nowadays, the MPN of Escherichia coli in molluscs is used in many countries in order to check fecal contamination and hygiene-sanitary conditions of both oysters and capture/culture site ${ }^{14}$.

The aim of this study was to evaluate fecal contamination (through E. coli and Enterococcus spp. most probable number) and to characterize the antimicrobial resistance profiles of Enterococcus spp. isolated from oysters (Crassostrea rhizophorae) that are normally collected by local fishermen in the Barra de Guaratiba Mangrove and sold either directly to the consumers or to local restaurants.

\section{MATERIALS AND METHODS}

\section{Samples Collection and Transport}

The molluscs were bought from local fishermen of the Barra de Guaratiba Mangrove, Rio de Janeiro. According to the description and oral report of the fishermen, the authors estimated the most probable points where the oysters may have been collected (north shore of Restinga da Marambaia - Latitude 23 $4^{\prime} 0^{\prime \prime} \mathrm{S}$ and Longitude $\left.43^{\circ} 36^{\prime} 0^{\prime \prime} \mathrm{W}\right)$. The molluscs were stored under controlled temperature $\left(6^{\circ}\right.$ 
to $8^{\circ} \mathrm{C}$ ) and transported to the Microbiological Quality Control Laboratory of Animal Origin Products of "Universidade Federal Fluminense".

\section{Sample Preparation}

After removing fouling, the oyster shelves were brushed and washed under running tap water and then dried with paper towel before being disinfected with $70 \%$ ethyl alcohol. Afterwards, oysters were opened in an asseptic way in order to shuck the meat and liquor. The number of oysters in each sample was defined to ensure a total mass of $50 \mathrm{~g}$ (this number was typically in the range of 10 to 15 oysters). One hundred and twenty three individuals with intact shelves were selected in order to obtain nine samples of $50 \mathrm{~g}$. Each sample was blended with $450 \mathrm{~mL}$ phosphate buffered saline (PBS; $7.65 \mathrm{~g} \mathrm{NaCl}, 0.724 \mathrm{~g} \mathrm{Na}_{2} \mathrm{HPO}_{4}$ \{anhydrous\}, $0.21 \mathrm{~g} \mathrm{KH}_{2} \mathrm{PO}_{4}$ in $1 \mathrm{~L}$ of distilled water, $\mathrm{pH} 7.4$ ) in order to generate dilution $10^{-1}$. From the $10^{-1}$ dilution, a subsequent $10^{-2}$ dilution was prepared, repeating said process until a $10^{-4}$ dilution was achieved.

\section{Determination of Most Probable Number (MPN) of Total Coliforms and Escherichia coli}

From each dilution in PBS, $1 \mathrm{~mL}$ aliquot was transferred to three tubes containing 10 $\mathrm{m} \ell$ of "Rapid HiColiform Broth" (Himedia ${ }^{\mathrm{TM}} \mathrm{M} 1453$ ). Afterwards, the tubes were incubated at $35^{\circ}$ to $37^{\circ} \mathrm{C}$ for a period of 18 to $24 \mathrm{~h}$. Then, the tubes with blue to green color were exposed to ultraviolet light $(366 \mathrm{~nm})$ to verify the development of blue fluorescence, that is characteristic for the presence of Escherichia coli. A drop of Kovacs reagent was added to the tubes with fluorescence. After two minutes it was possible to check the formation of a red ring in the surface of the tube, what indicates positive indole production. The tubes with positive results in all of these tests were considered in the calculation of MPN of Escherichia coli.

\section{Isolation and Presumptive Identification of Enterococcus}

From each dilution in PBS, $1 \mathrm{~m} \ell$ aliquot was transferred to three tubes containing $10 \mathrm{~m} \ell$ of "HiCrome Enterococci Broth" (Himedia ${ }^{\mathrm{TM}}$ M1376). Afterwards, the tubes were incubated at $35^{\circ}$ to $37^{\circ} \mathrm{C}$ for a period of $48 \mathrm{~h}$. The tubes with green to blue color were positive for the presence of Enterococcus spp. An aliquot of $100 \mu \mathrm{L}$ from each positive tube was tested on agar m-enterococos (BD Difco ${ }^{\mathrm{TM}} 274620$ ), that was incubated at $35^{\circ} \mathrm{C}$ for $48 \mathrm{~h}$. Afterwards, three to five colonies (red color due to positive test related to the reduction of 2,3,5-triphenyl-2H-tetrazolium chloride) were transferred to tubes containing brain heart infusion (BHI; BD Difco ${ }^{\mathrm{TM}} 237500$ ) and incubated at $37^{\circ} \mathrm{C}$ for $24 \mathrm{~h}$. The phenotypic tests for the presumptive analysis of the strains were: gram stain morphology; negative-catalase test after growth in TSA (TSA; BD Difco ${ }^{\mathrm{TM}} 236950$ ); growth in TSB (TSB; BD Difco ${ }^{\mathrm{TM}} 211825$ ) with $\mathrm{pH} 9.6$ $\left(37^{\circ} \mathrm{C}\right.$ for $\left.24 \mathrm{~h}\right)$; growth in TSB with $6.5 \% \mathrm{NaCl}\left(37^{\circ} \mathrm{C}\right.$ for $\left.24 \mathrm{~h}\right)$; growth in TSB at $45^{\circ} \mathrm{C}$; bile-esculin agar test $\left(37^{\circ} \mathrm{C}\right.$ for $\left.48 \mathrm{~h}\right)$; Pyrrolidonyl Arylamidase test (PYR; PROBAC DO BRASIL ${ }^{\mathrm{TM}}$, PYR TEST).

\section{Antimicrobial Susceptibility Testing}

The disk diffusion susceptibility method was used and the test was performed by applying a bacterial inoculum $(0.85 \%$ sterile saline solution with turbidity equivalent to 0.5 standard in the McFarland scale, corresponding to approximately $\left.1 \times 10^{8} \mathrm{CFU} / \mathrm{mL}\right)$ to the surface of a large $(150 \mathrm{~mm}$ diameter) Mueller-Hinton agar (BD Difco $\left.{ }^{\mathrm{TM}} 225250\right)$ plate. An antibiotic multi-test disc with 12 antimicrobial agents (DME - Polisensidisc 12 Enterococcus spp.) was placed on the inoculated agar surface. Plates were incubated for $24 \mathrm{~h}$ at $35^{\circ} \mathrm{C} \pm 2{ }^{\circ} \mathrm{C}$ prior to determination of results. The zones of growth inhibition around each of the antibiotic disks were 
measured to the nearest millimeter. The following antimicrobial agents were tested: levofloxacin - LEV $(5 \mu \mathrm{g})$, teicoplanin - TEC $(30 \mu \mathrm{g})$, norfloxacin - NOR $(10 \mu \mathrm{g})$, penicillin - PEN $(10 \mu \mathrm{g})$, linezolide - LNZ $(30 \mu \mathrm{g})$, ampicillin - AMP $(10 \mu \mathrm{g})$, ciprofloxacin - CIP $(5 \mu \mathrm{g})$, nitrofurantoin - NIT $(300 \mu \mathrm{g})$, tetracycline - TET $(30 \mu \mathrm{g})$, streptomycin - EST $(300 \mu \mathrm{g})$, gentamicin - GEN $(120 \mu \mathrm{g})$ and vancomycin - VAN $(30 \mu \mathrm{g})$. Results were interpreted according to Clinical and Laboratory Standards Institute $^{15}$. Reference strains were Staphylococcus aureus ATCC 25923 and Enterococcus faecalis ATCC 29212 and ATCC 51575.

\section{Statistical Analysis}

For each enumeration, a statistical analysis was performed (mean, median, first and third quartiles, variance, standard deviation). Pearson product-moment correlation coefficient was used to investigate potential correlation for each pair of microorganisms.

\section{RESULTS AND DISCUSSION}

\section{Total Coliforms Most Probable Number (MPN)}

MPN for Total Coliforms were in the range of 23/g to 460/g (263/g mean; 95\% confidence interval from 112/g to 413/g; 196/g standard deviation).

\section{Escherichia coli Most Probable Number (MPN)}

MPN for Escherichia coli were in the range of 9.2/g to 93/g (32.6/g mean; 95\% confidence interval from $8.44 / \mathrm{g}$ to $56.8 / \mathrm{g} ; 31.5 / \mathrm{g}$ standard deviation). E. coli was identified in $100 \%$ of the samples. Pearson productmoment correlation coefficient was 0.7 for total coliforms and Escherichia coli (meaning a good correlation). The Escherichia coli MPN values in all samples exceeded the limits established by Brazilian bivalve molluscs legislation ${ }^{16,17}$ and by many other countries legislation ${ }^{14}$. According to the Brazilian legislation ${ }^{17}$ and to the legislations from European Union, China, Italy and New Zealand, the capture site would be classified as conditioned zone, class $\mathrm{C}$, class 3 , conditioned zone and restricted zone, respectively ${ }^{14}$ which means that all samples should be processed before being either consumed or marketed in order to reduce the bacterial load and the risk of foodborne diseases. Despite this, during field work it was observed that these oysters are eaten raw by consumers purchasing either directly from fishermen or in local restaurants in Barra de Guaratiba.

\section{Enterococcus spp. MPN and correlation to E. coli MPN}

MPN for Enterococcus spp. were in the range of 3.6/g to 93/g (28.2/g mean; 95\% confidence interval from $6.58 / \mathrm{g}$ to $49.9 / \mathrm{g} ; 28.2 / \mathrm{g}$ standard deviation). Pearson product-moment correlation coefficient was -0.286 (meaning no correlation) for total coliforms and Enterococcus spp. Pearson productmoment correlation coefficient was -0.310 (meaning no correlation) for E. coli and Enterococcus spp. MPN mean, quartiles, 95\% confidence interval and standard deviation are represented in the graph on Figure 1. 


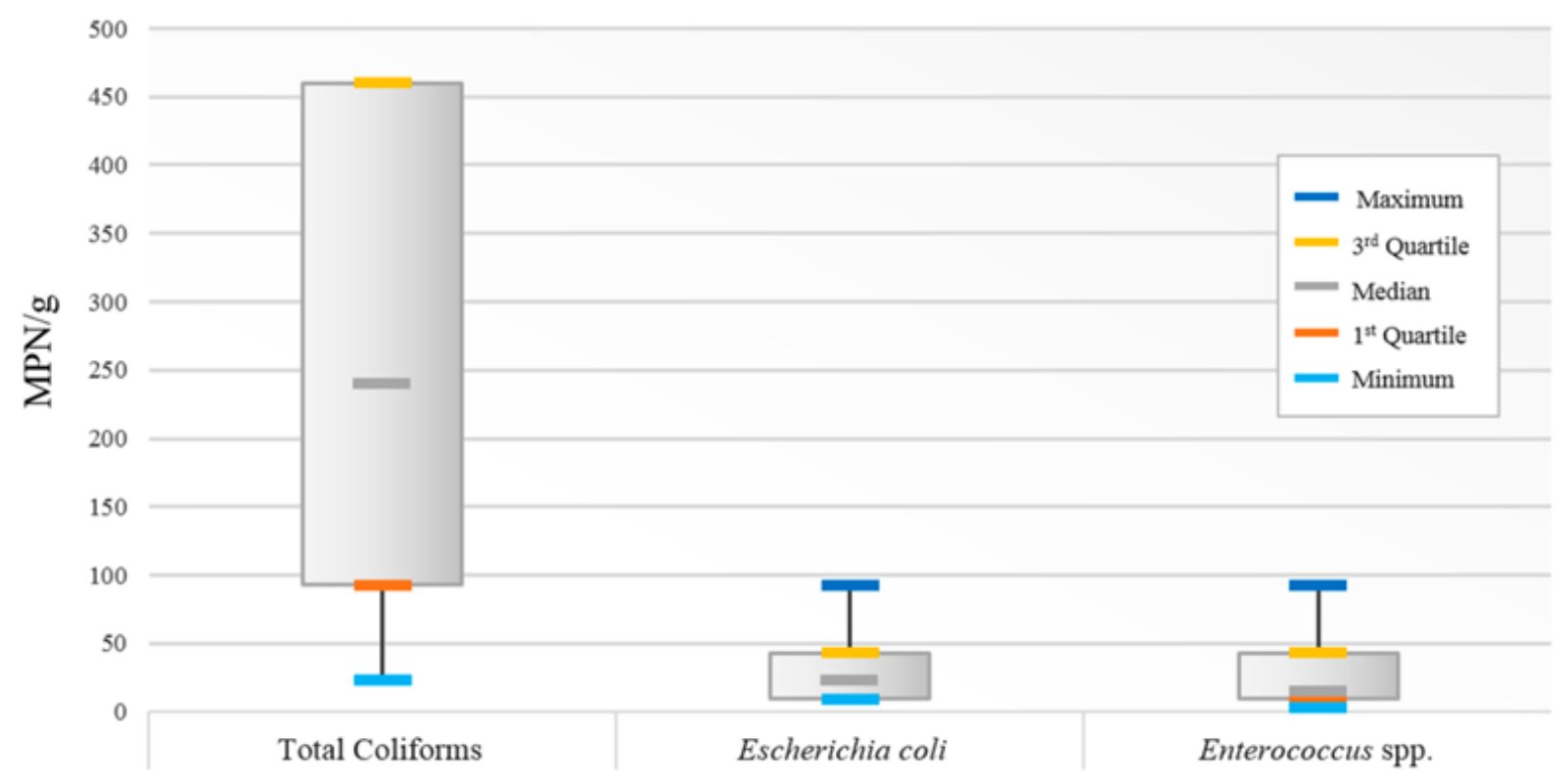

Figure 1 - Total Coliforms, Escherichia coli and Enterococcus spp. MPN with statistical parameters.

Fernández-Delgado and Suárez ${ }^{18}$, Silva et al. ${ }^{19}$ and Morelli et al. ${ }^{20}$, analyzing Crassostrea rhizophorae samples and Fernández-Delgado and Suárez ${ }^{18}$, in their study of Isognomon alatus, found MPN values to Enterococcus spp. from 16,000/g to $\geq 160,000 / \mathrm{g}$, with means of $217.6 / \mathrm{g}$ and $242 / \mathrm{g}$ and from $200 / \mathrm{g}$ to $800 / \mathrm{g}$, respectively, that are significantly higher MPN values than the ones from the present study. Soares et al. $^{21}$, analyzed Nodipecten nodosus samples and found no Enterococcus spp. not in accordance with the present study. The analysis of Mytilus edulis, Mytilus galloproviciallis and Cerastoderma edule samples by Bennani et al. ${ }^{22}$ indicated an Enterococcus spp. MPN mean of 25/g for one site they studied that was a result very similar to the one that we had in the present work. For the second site, however, the same authors found an MPN mean of 500/g that was also significantly higher than the value founded in the present study. Is was noted that the level of contamination by Enterococcus spp. in the oysters studied was much lower than the level determined in other studies involving Crassostrea rhizophorae or different bivalve molluscs.

\section{Antimicrobial Resistance Profile (AMR) for Enterococcus spp.}

Among the 93 Enterococcus spp. isolates, 13 (14.0\%) were susceptible to all antimicrobial agents and $80(86 \%)$ were resistant at least to one antimicrobial agent analyzed in the present study (table 1). The majority (69.9\%) of the isolates presented intermediate resistance to ciprofloxacin and $33.3 \%$ presented resistance to tetracycline (table 2). No resistance was detected to the following antimicrobial agents: ampicillin $(10 \mu \mathrm{g})$, penicillin $(10 \mathrm{u})$, teicoplanin $(30 \mu \mathrm{g})$, levofloxacin $(5 \mu \mathrm{g})$, linezolide $(30 \mu \mathrm{g})$ and gentamicin $(120 \mu \mathrm{g})$.

Table 1 - Number of isolates with antimicrobial resistance per set of antimicrobial agents.

\begin{tabular}{lll}
\hline Sets of antimicrobial agents & $\begin{array}{l}\text { Number of } \\
\text { Isolates }\end{array}$ & Frequency (\%) \\
\hline Tetracycline, Streptomycin, Ciprofloxacin (I) and Norfloxacin (I) & 1 & 1.1 \\
Tetracycline, Streptomycin and Ciprofloxacin (I) & 1 & 1.1 \\
\hline
\end{tabular}




\begin{tabular}{lll}
\hline Vancomycin (I), Ciprofloxacin (I) and Norfloxacin (I) & 1 & 1.1 \\
Tetracycline, Ciprofloxacin (I) and Norfloxacin (I) & 7 & 7.5 \\
Tetracycline and Nitrofurantoin & 5 & 5.4 \\
Tetracycline and Ciprofloxacin (I) & 12 & 12.9 \\
Ciprofloxacin and Norfloxacin (I) & 2 & 2.2 \\
Tetracycline and Norfloxacin (I) & 2 & 2.2 \\
Ciprofloxacin (I) and Norfloxacin (I) & 19 & 20.4 \\
Tetracycline & 3 & 3.2 \\
Tetracycline (I) & 1 & 1.1 \\
Ciprofloxacin (I) & 24 & 25.8 \\
Norfloxacin (I) & 2 & 2.2 \\
Susceptible to all antimicrobial agents & 13 & 14.0 \\
Total & 93 & 100.0 \\
\hline
\end{tabular}

NOTE: (I) indicates Intermediate Resistance.

Table 2 - AMR profile - frequency distribution per antimicrobial agents

\begin{tabular}{llll}
\hline Antimicrobial agent & Susceptible (\%) & $\begin{array}{l}\text { Intermediate } \\
\text { resistance (\%) }\end{array}$ & Resistant (\%) \\
\hline tetracycline & 65.6 & 1.1 & 33.3 \\
streptomycin & 97.8 & 0.0 & 2.2 \\
ciprofloxacin & 28.0 & 69.9 & 2.2 \\
norfloxacin & 63.4 & 36.6 & 0.0 \\
nitrofurantoin & 94.6 & 0.0 & 5.4 \\
vancomycin & 98.9 & 1.1 & 0.0 \\
\hline
\end{tabular}

The isolates were also evaluated according to the quantity of antimicrobial categories they were resistant to (Fig. 2).

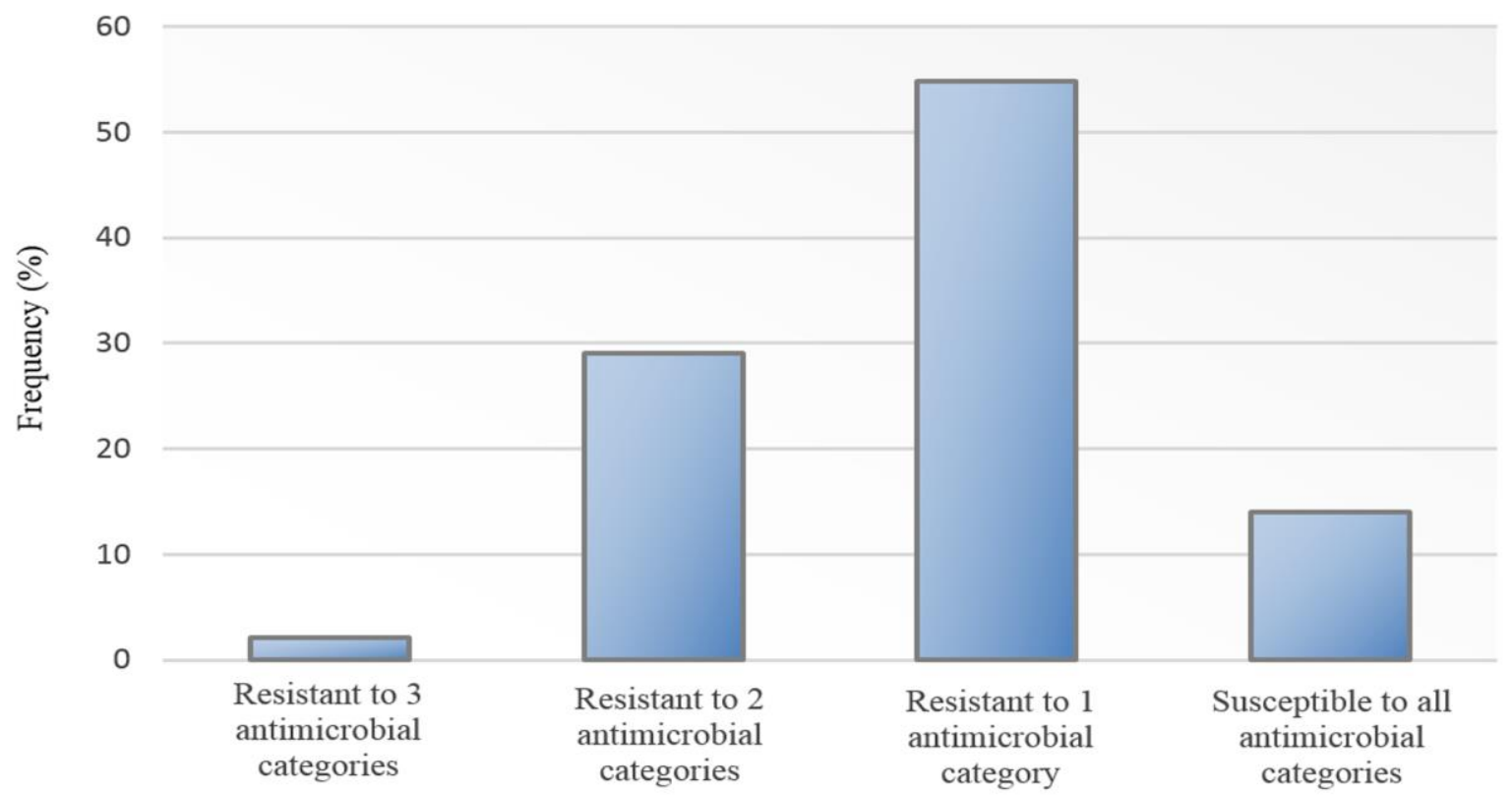

Figure 2 - Frequency distribution of isolates according to the quantity $(0,1,2,3)$ of antimicrobial categories they were resistant to. 
The most relevant result in the present study was the identification of Enterococcus spp. isolates that were resistant to agents from three different categories of antimicrobial drugs (including high-level resistance to streptomycin, fluoroquinolones and tetracyclines) and with intermediate resistance to vancomycin. Vancomycin is an antimicrobial drug extensively used to treat infections caused by resistant Enterococcus spp. and is also used to treat serious infections caused by other Gram-positive bacteria ${ }^{23}$. Is important to note the high incidence of resistance to ciprofloxacin, a broad-spectrum antimicrobial agent of the fluoroquinolone category that is frequently used for treatment of endovascular enterococcal infections. Besides this, there is a possibility of these isolates transfer plasmidmediated ciprofloxacin resistance genes to different pathogenic bacteria, according to the study of Strahilevitz et $\mathrm{al}^{24}$. Due to the clinical importance of ciprofloxacin, Magiorakros et al. ${ }^{25}$ mention it as one of the agents considered in MDR evaluation tables.

In the present study, $86.0 \%$ of the Enterococcus spp. isolates were resistant to at least one antimicrobial agent. Bennani et al. ${ }^{22}$ found $54.4 \%$ and Fernández-Delgado and Suárez ${ }^{18}$ found $100 \%$ of the Enterococcus spp. isolates with some AMR. In the present study, only one isolate presented an intermediate resistance to vancomycin, that is a similar result to the ones obtained by Bennani et al. ${ }^{22}$ (only $4.3 \%$ of isolates were vancomycin resistant). No isolate was resistant to teicoplanin. This result was expected because both vancomycin and teicoplanin are injectable drugs for restricted use in hospitals. Typically, vancomycin and teicoplanin resistant Enterococcus are found only either in hospitals or in water bodies receiving hospitals effluent. Bennani et al..$^{22}$ found $7.6 \%$ and $10.8 \%$ of isolates with high-level resistance to streptomycin and gentamycin, respectively. For these drugs the percentages of resistance in the present study were considerably lower: $2.2 \%$ and $0 \%$, respectively. While ampicillin resistance was observed in both the studies of Bennani et al. ${ }^{22}$ and FernándezDelgado and Suárez ${ }^{18}$ (4.3\% and $20.0 \%$, respectively), no ampicillin resistant strain was found in the present study. A higher percentage (33.3\%) of Enterococcus spp. isolates from this study were resistant to tetracycline when compared with the percentage $(18.5 \%)$ found by Bennani et al. ${ }^{22}$ in their study. Although enterococci resistance to tetracycline is frequent in clinical isolates and in food of animal origin, their high incidence in the oysters analyzed indicates a relevant pollution of mangrove environment, since the acquired resistance to tetracycline among enterococci isolates is very common due to antimicrobial selective pressure in this

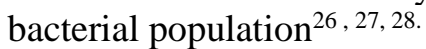

\section{CONCLUSIONS}

In the present study, a reasonably complex antimicrobial resistance profile was identified, with strains that were resistant either to multiple agents (three to four agents from three different antimicrobial classes - tetracyclines, fluoroquinolones and aminoglycosides) or to clinically relevant agents for enterococcal infections like vancomycin, streptomycin (high-level dosage) and ciprofloxacin.

In conclusion, Crassostrea rhizophorae oysters (mangrove oysters) from the Barra de Guaratiba Mangrove were significantly contaminated by Escherichia coli, in addition to a relevant antimicrobial resistant Enterococcus spp. bacteria. As bioindicators, bivalve molluscs reflect the water quality and their microbiological analysis has been employed in many countries to detect water pollution. Therefore, the contamination of the analysed oysters indicates a potential contamination of other shellfish collected in that area. This may represent a public health concern since these shellfish are consumed and trade by fishermen of that coastal community. Additionally, the water pollution represents a threat for the mangrove environment 
that supports a range of wild animal species. Processes like depuration, relaying, cooking, irradiation and heat pasteurization prior to trade and consumption can be used to reduce the bacterial load and the risk of foodborne diseases. Further studies are needed in order to investigate the impact of water pollution in the Barra de Guaratiba mangrove environment.

\section{ACKNOWLEDGMENTS}

The authors thank Larissa Alvarenga Batista Botelho, Ronaldo Hertel Neira and the team of the Laboratory of Food Microbiology at Instituto Prof. Paulo de Góes of "Universidade Federal do Rio de Janeiro" for all the technical support. This research was partially supported by National Council of Scientific and Technological Development of Brazil (CNPq).

\section{REFERENCES}

1- UNEP. United Nations Environment Programme. The Importance of Mangroves to People: A Call to Action. Cambridge: United Nations Environment Programme World Conservation Monitoring Centre. 2014. [cited 2015 Nov 1]. Available from:

http://www.unepwcmc.org/system/dataset_file_fields/files/000/000/275/original/DEPI_Mang rove_ES_report_complete_Low_Res.pdf?1416237427.

2- Anastasi EM, Matthews B, Stratton HM, Katoulia M. Pathogenic Escherichia coli Found in Sewage

Treatment Plants and Environmental Waters. Appl Environ Microbiol. 2012. 78(16): 5536-5541.

3- Borhani K, Ahmadi A, Rahimi F, Pourshafie MR, Malihe T. Determination of Vancomycin Resistant Enterococcus faecium Diversity in Tehran Sewage Using Plasmid Profile, Biochemical Fingerprinting and Antibiotic Resistance. Jundishapur J Microbiol. 2014; 7(2): e8951.

4- World Health Organization (WHO). WHO's first global report on antibiotic resistance reveals serious, worldwide threat to public health. 2014 Jun [cited 2015 Nov 1]. Available from:

http://www.who.int/mediacentre/news/releases/2014/amr-report/en/.

5- Huddleston J.R. Horizontal gene transfer in the human gastrointestinal tract: potential spread of antibiotic resistance genes. Infect Drug Resist. 2014; 7: 167-176.

6- Centers for Disease Control and Prevention (CDC). Vancomycin-resistant Staphylococcus aureus-New York, Morbity and Mortality Weekly Report. 2004; 53 (15): 322-323.

7- Chang S, Sievert DM, Hageman JCM, Boulton L, Tenover FP, Downes FC, et al. Infection with vancomycin-resistant Staphylococcus aureus containing the vanA resistance gene. New Engl J Med. 2003; 348: 1342-1347.

8- Courvalin P. Transfer of Antibiotic Resistance Genes between Gram-Positive and GramNegative Bacteria. Antimicrob Agents Ch. 1994; 38(7): 1447-1451.

9- Kurenbach B, Bohn C, Prabhu J, Abudukerim M, Szewzyk U, Grohmann. E. Intergeneric transfer of the Enterococcus faecalis plasmid pIP501 to Escherichia coli and Streptomyces lividans and sequence analysis of its tra region. Plasmid. 2003; 50: 86-93.

10-Tenover FC, Weigel LM, Appelbaum PC, Mcdougal LK, Chaitram J, Mcallister S, et al. Vancomycin-resistant Staphylococcus aureus isolate from a patient in Pennsylvania. Antimicrob Agents Ch. 2004; 48: 275-280.

11-Weigel LM, Clewell DB, Gill SR, Clark NC, McDougal LK, Flannagan SE, et al. Genetic analysis of a high-level vancomycin-resistant isolate of Staphylococcus aureus. Science. 2003; 302: 1569-1571.

12-Hollenbeck BL, Rice LB. Intrinsic and acquired resistance mechanisms in Enterococcus. Virulence. 2012; 3(5): 421-569.

13-Kayser FH. Safety aspects of enterococci from the medical point of view. Int J Food Microbiol. 2003; 88: 255-262. 
14-Rees G, Liu H, Fang J, Karasungar I. Current management practices in: Safe Management of Shellfish and Harvest Waters. World Health Organization (WHO). 2010 [cited 2015 Oct 10]. Available from: http://apps.who.int/iris/bitstream/10665/44101/1/9789241563826_eng.pdf. Acesso em: 10 out. 2015.

15-CLSI. M100-S24 Performance Standards for Antimicrobial Susceptibility Testing; Twenty-Fourth Informational Supplement. 2014; M100-S24.

16-Brasil. Ministério da Pesca e Aquicultura (MPA) e Ministério da Agricultura, Pecuária e Abastecimento (MAPA). Instrução Normativa Interministerial $\mathrm{n}^{\circ} 7$, de 8 de maio de 2012. Institui o Programa Nacional de Controle Higiênico-Sanitário de Moluscos Bivalves (PNCMB), estabelece os procedimentos para a sua execução e dá outras providências. Diário Oficial da União, Brasília, DF, n. 89, p.55, 9 maio 2012. Seção 1.

17-Brasil. Ministério da Pesca e Aquicultura (MPA). Portaria n ${ }^{\circ}$ 175, de 15 de Maio de 2013. Acresce dispositivos à Portaria MPA n ${ }^{\circ}$ 204, de 28 de junho de 2012. Diário Oficial da União, Brasília, DF, n. 93, p.57, 16 maio 2013. Seção 1.

18-Fernández-Delgado M, Suárez P. Multiple antibiotic resistances of enteric bacteria isolated from recreational coastal waters and oysters of the Caribbean Sea. Ann Microbiol. 2009; 59 (3): 409-414.

19-Silva AIM, Vieira RHSF, Menezes FGR, Fonteles-Filho A, Torres RCO, Sant'Anna ES. Bacteria of fecal origin in mangrove oysters (Crassostrea rhizophorae) in the Coco River estuary, Ceará State, Brazil. Braz J Microbiol. 2003; 34: 126-130.

20-Morelli AM, Vieira RHSF, Reis CMF, Rodrigues DP, Fonteles-Filho AA. Indicadores de contaminação fecal para ostra-do-mangue (Crasssotrea rhizophorae) comercializada na Praia do Futuro, Fortaleza, Ceará. R Hig Alim. 2003; 17: 81-88.

21-Soares IC, Mesquita EFM, Franco RM, Vital HC, Rubião CA. Análise bacteriológica de músculo e gônadas de vieira, Nodipecten nodosus (Mollusca: Bivalvia), congelados e irradiados. Braz J Vet Res Anim Sci. 2012; 49 (1): 24-29.

22-Bennani M, Amarouch H, Oubrim N, Cohen N. Identification and antimicrobial resistance of fecal Enterococci isolated in coastal mediterranean environments of Morocco. Eur J Sci Res. 2012; 70: 266-275.

23-Bruniera FR, Ferreira FM, Saviolli, LR, Bacci MR, Feder D, Pedreira MLG, et al. The use of vancomycin with its therapeutic and adverse effects: a review. Eur Ver Med Pharmacol Sci. 2015; 19: 694-700.

24-Strahilevitz J, Jacoby GA, Hooper DC, Robicsek A. Plasmid-mediated quinolone resistance: a multifaceted threat. Clin Microbiol Rev. 2009; 22: 664-689.

25-Magiorakos AP, Srinivasan A, Carey RB, Carmeli Y, Falagas ME, Giske CG, et al. Multidrug-resistant, extensively drug-resistant and pandrug-resistant bacteria: an international expert proposal for interim standard definitions for acquired resistance. Clin Microbiol Infec. 2014; 18 (3): 268-281.

26-Choi JM, Woo GJ. Transfer of Tetracycline Resistance Genes with Aggregation Substance in Food-Borne Enterococcus faecalis. Curr. Microbiol. 2015; 70: 476-484.

27-Garrido AM, Gálvez A, Pulido RP. Antimicrobial Resistance in Enterococci. Infect Dis Ther. 2014; 2: 4.

28-Young S, Juhl A, O'Mullan GD. Antibiotic-resistant bacteria in the Hudson River Estuary linked to wet weather sewage contamination. J Water Health. 2013; 11 (2): 297-310. 


\section{Erratum}

In Article "Enterococcus spp. Resistant to Multiple Antimicrobial Drugs and Determination of Fecal Contamination Levels in Mangrove Oysters (Crassostrea rhizophorae)", with DOI number: http://dx.doi.org/10.1590/1678-4324-2017160127, published in journal Brazilian Archives of Biology and Technology, vol. 60, the 01 page.

That read:

“http://dx.doi.org/10.190/1678-4324-2017160127”

Read:

“http://dx.doi.org/10.1590/1678-4324-2017160127" 